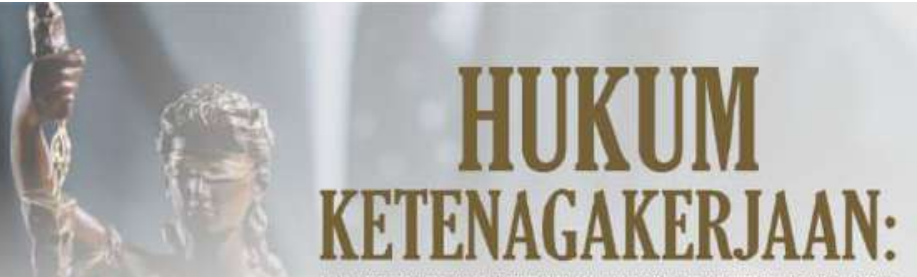

ANAUISIS PUTUSAN IIA TENIANG NOGOK KERUA YANG UENGAKIBATKAN PHK

Buku ini merupakan hasil penelitan penulis terkait persoalan mogok kerja yang mengakibatkan PHK yang akhir-akhir ini marak terjadi dalam hubungan industrial. Buku ini disajikan untuk melengkapi literatur baik untuk kebutuhan akademik maupun referensi praktisi dalam bidang hukum ketenagakejjaan. Penyajian ini menjadi penting, karena pada dasarnya mogok kerja adalah merupakan hak bag pekerja namun tidak jarang berakhir pada pemutusan hubungan kerja. Dengan hadirnya buku ini diharapkan para pelaku hubungan industrial baik pekerja, pengusaha dan pemerintah dapat memahamihakikat dari mogok kerja. Oleh karena itu, buku ini perlu dimiliki dan cibaca, terutama bagi mahasiswa yang sedang belajar hukum ketenagakerjaan termasuk masyarakat secara keseluruhan.

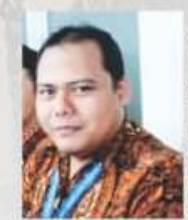

Abdul Hadi, S.H, M.H

Lahir di Tangerang tanggal 5 Februari 1987. Pendidikan Sekolah Dasar diselesaikan di SDN Poris Plawad 04 Tangerang tahun 1999. Sekolah Menengah Pertama diselesaikan di Madrasah Tsanawivah Asy

Syukriyyah Tangerang tahun 2002 kemudian melanjutkan ke Madrasah Alyah Negeri Cipondoh tahun 2005. Sarjana Hukum (S1) diperoleh dari Fakultas Hukum Universitas Pamulang pada tahun 2014. Gelar Magister Hukum (S2) diperoleh dari Program Pasca Sariana Universitas Pamulang tahun 2017.

Riwayat pekerjaan dimulai sejak menyelesaikan pendidikan MA pada tahun 2005 dan mulai memasuki dunia industri hingga tahun 2015. Pengalamen yang diperoleh baik praktik maupun teoritik telah menghantarkan pada prestasi akademik sebagai lulusan terbaik (S1) universitas Pamulang pada tahun 2015 dengan predikat Cumlaude. Lulus tahun 2017 dari Program Pasca Sajjana Universitas Pamulang mendedikasikan diri pada dunia akademik, dan pada bulan Agustus 2017 diangkat sebagai dosen tetap universitas Pamulang. Selain sebagai dosen juga aktif dalam organisasi diantaranya, Sekretaris Lembaga Bantuan Hukum (LBH) Unggul Tangerang Selatan, Anggota Persatuan Advokat Indonesia (PERADIN), Anggota jurnalis Media Online Visione.cos.id dan lain-lain.

Adapun penelitian penulis selama tiga tahun terakhir diantaranya, tinjauan yuridis normatif tentang mekanisme penentuan upah minimum di Indonesia (studi komparatif mekanisme penetapan upah minimum sebelum dan sesudah terbitnya PP No. 78 tahun 2015 tentang pengupahan), fenomena menikah dengan teman sekantor pasca putusan MK tentang uji materi pasal 153 ayat 1 huruf $F$ UU No. 13 Tahun 2003 tentang ketenagakerjaan, Perlindungan hukum terhadap karyawan yang mengalami PHK setelah putusan pengadilan yang berkekuatan hukum tetap, dan lain-lain.

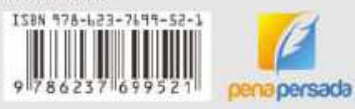

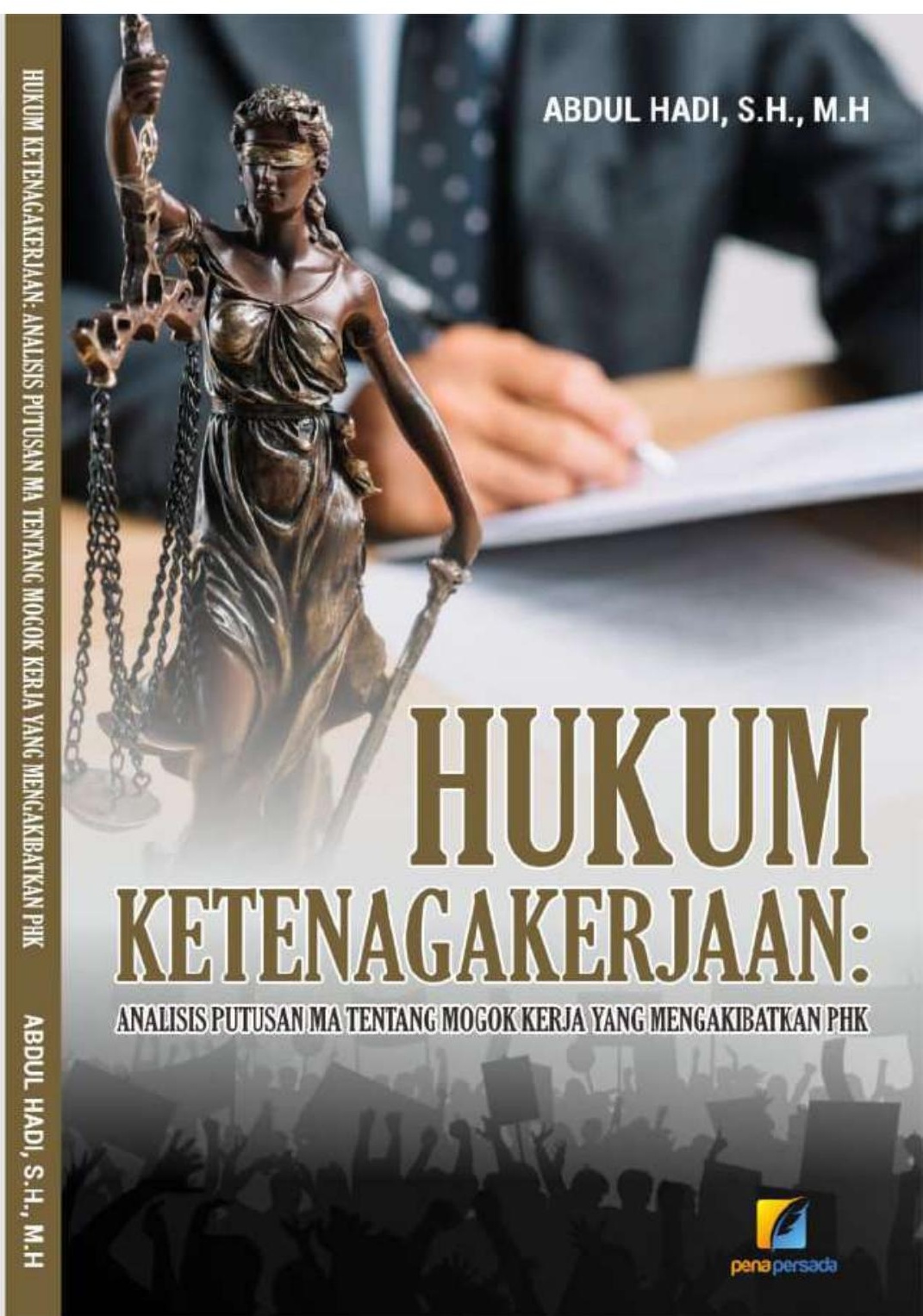




\title{
HUKUM KETENAGAKERJAAN: \\ ANALISIS PUTUSAN MA TENTANG MOGOK KERJA YANG MENGAKIBATKAN PHK
}

\author{
Abdul Hadi, S.H., M.H
}

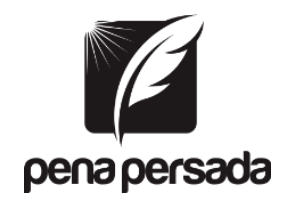

PENERBIT CV. PENA PERSADA 


\title{
HUKUM KETENAGAKERJAAN: \\ ANALISIS PUTUSAN MA TENTANG MOGOK KERJA YANG MENGAKIBATKAN PHK
}

\author{
Penulis : \\ Abdul Hadi, S.H., M.H \\ Editor: \\ Wiwit Kurniawan, M.A \\ ISBN : 978-623-7699-52-1 \\ Desain Sampul : \\ Retnani Nur Briliant \\ Penata Letak : \\ Fajar T. Septiono

\section{Penerbit CV. Pena Persada} \\ Redaksi : \\ Jl. Gerilya No. 292 Purwokerto Selatan, Kab. Banyumas \\ Jawa Tengah \\ Email : penerbit.penapersada@gmail.com \\ Website : penapersada.com \\ Phone : (0281) 7771388
}

\section{Anggota IKAPI}

All right reserved

Cetakan pertama : 2020

Hak Cipta dilindungi oleh undang-undang.

Dilarang memperbanyak karya tulis ini dalam bentuk dan cara apapun tanpa izin penerbit. 


\section{KATA PENGANTAR}

$$
\text { ح يم الزّ حمن الرّ الله بـ سم }
$$

Assalamu'alaikum, $W r . W b$

Alhamdulillahirrobbil'alamiiiiiiin.Segala puji dan syukur bagi Allah SWT, yang telah memberi nikmat kepada makhluk-Nya yang tidak terhingga. Shalawat beriring salam dijunjungkan pada Nabi Muhammad SAW yang telah memberikan petunjuk yang benar pada semua umatnya, sehingga penulis dapat menyelesaikan penulisan buku ini tepat pada waktunya. Buku ini merupakan hasil dari penelitian penulis berupa tesis dengan judul "Kajian yuridis terhadap putusan Mahkamah Agung Nomor 13 K/Pdt.Sus- PHI/2015 tentang mogok kerja yang mengakibatkan pemutusan hubungan kerja ditinjau dari Undang-Undang Nomor 13 Tahun 2003 tentang ketenagakerjaan" pada Program Pascasarjana Universitas Pamulang.

Secara garis besar, buku ini membahas tentang aspek hukum terhadap kasus mogok kerja yang menyebabkan pemutusan hubungan kerja. Hubungan kerja yang dilakukan setelah adanya Perjanjian Kerja Bersama tidak menjamin hubungan antara pekerja dengan pengusaha berjalan seperti apa yang diharapkan. Pekerja karena tuntutan ekonomi lebih berpandangan kepada kesejahteraan kerja yang maksimal namun pengusaha lebih berprioritas pada produktifitas dan sekecil mungkin meminimalisir biaya produksi.

Dari dua pandangan yang berbeda ini perselisihan antara pekerja dengan pengusaha sulit dihindari. Pekerja adalah tulang punggung pembangunan, industri tidak akan berjalan tanpa adanya pekerja. Namun posisi tersebut tidak menjadikan pekerja mempunyai Bargening Position yang kuat di dalam suatu hubungan kerja. Penelitian ini menganalisis bentuk putusan Mahkamah Agung No. 13 K/Pdt.Sus- PHI/2015 tentang mogok kerja yang mengakibatkan pemutusan hubungan kerja. Kemudian bentuk-bentuk dari mogok kerja yang dapat mengakibatkan pemutusan hubungan kerja ditinjau berdasarkan Undang-Undang No. 13 Tahun 2003 tentang Ketenagakerjaan. 
Metode penelitian ini berdasarkan pada metode penelitian normatif empiris dengan metode pendekatan preskripsi yang tujuannya memberikan petunjuk. Data primer dalam penelitian ini penulis peroleh dari Mahkamah Agung melalui salinan putusan Nomor 13 K/Pdt.Sus-PHI/2015. Kemudian data-data sekunder yang diperoleh melalui studi kepustakaan dengan mengumpulkan bahan-bahan tertulis yang berhubungan dengan penelitian, yaitu seperti peraturan perundang- undangan, buku-buku, jurnal dan lain sebagainya.

Berdasarkan penelitian penulis mendapatkan bentuk putusan Mahkamah Agung Nomor 13 K/Pdt.Sus- PHI/2015 tentang mogok kerja yang mengakibatkan pemutusan hubungan kerja yaitu dengan membatalkan putusan mempekerjakan kembali Pengadilan Hubungan Industrial Serang Nomor 06/PHI.G/2014/PN.Srg, tanggal 20 Agustus 2014. Menyatakan pengusaha secara sah dapat melakukan Pemutusan Hubungan Kerja kepada para pekerja dengan menghukum pengusaha membayar uang pesangon sebesar 1 (satu) kali ketentuan Pasal 156 Ayat 2, uang penghargaan masa kerja sebesar 1 (satu) kali ketentuan Pasal 156 Ayat 3 dan uang penggantian hak sesuai ketentuan Pasal 156 Ayat 4 Undang-Undang Nomor 13 Tahun 2003 tentang Ketenagakerjaan.

Bentuk mogok kerja yang bisa mengakibatkan pemutusan hubungan kerja ditinjau dari Undang-Undang Nomor 13 Tahun 2003 tentang Ketenagakerjaan adalah mogok kerja yang dilakukan secara tidak sah atau bukan akibat gagalnya perundingan, tanpa pemberitahuan pada pengusaha dan instansi yang bertanggung jawab di bidang ketenagakerjaan, pemberitahuan kurang dari 7 (tujuh) hari sebelum pelaksanaan mogok kerja, pemberitahuan tidak sesuai dengan ketentuan Pasal 140 Ayat 2 Huruf a, b, c, dan d Undang-Undang Nomor 13 Tahun 2003 tentang ketenagakerjaan.

Penulis mengucapkan banyak terima kasih sebesar-besarnya kepada semua pihak yang telah membantu penyusunan buku ini. Penulis menyadari benar bahwa dalam penulisan buku ini tidak dapat lepas dari bantuan dan dorongan dari semua pihak baik 
dalam bentuk moril dan materil serta informasi yang dibutuhkan dalam penyusunan buku ini yang diharapkan dapat memperkaya koleksi bahan bacaan khususnya dalam ranah hukum ketenagakerjaan. Kemudian pada kesempatan ini penulis mengucapkan terima kasih yang sebesar-besarnya kepada Kedua orang tua tercinta Ibunda Napsiah dan ayahanda Marsin yang dengan penuh kesabaran dan pengorbanannya memberikan dorongan dan do'a yang tidak pernah putus. Kepada Pimpinan Universitas Pamulang beserta civitas akademik Universitas Pamulang. Kepada istri tercinta Maya Mufrida dan putra tersayang Afnan Fadhilah Attaqi. Kepada keluarga besar kakak dan adik, teman, penerbit beserta sahabat. Semoga Allah SWT senantiasa melindungi kita semua. Amiiin.

Akhirnya penulis menyadari bahwa buku ini belum bisa sepenuhnya dapat mengisi dahaga wawasan ilmiah para intelektualitas semuanya, untuk itu penulis amat berlapang dada untuk menerima segala masukan-masukan atau kritik yang konstruktif untuk kesempurnaan buku ini. Semoga buku ini pada akhirnya dapat memberikan informasi dan konstribusi yang positif bagi penulis khususnya dan pembaca umumnya serta dapat berguna untuk pengembangan ilmu pengetahuan serta khasanah kepustakaan.

\section{Penulis}

Abdul Hadi, S.H., M.H 


\section{DAFTAR ISI}

BAB I PERSOALAN HUKUM DAN TENAGA KERJA .............. 1

A. Hukum Ketenagakerjaan dan Permasalahannya.................. 1

B. Fokus Masalah dan Tujuan Kajian ........................................ 12

C. Teori Hukum dan Keadilan ................................................... 13

1. Teori Kedaulatan Hukum Hugo Krabble ......................... 13

2. Teori Keadilan John Rawls .............................................. 17

3. Teori Hukum Roscoe Pound ............................................. 21

D. Preposisi _..................................................................... 24

BAB II MOGOK KERJA DAN TINJAUAN HUKUMNYA ....... 26

A. Pengertian Mogok Kerja ...................................................... 26

B. Syarat Sah Mogok Kerja............................................................ 26

C. Jenis-Jenis Mogok Kerja .......................................................... 30

1. Mogok Kerja Berdasarkan Tuntutan ................................. 30

2. Mogok Kerja Berdasarkan Lokasi...................................... 31

3. Mogok Kerja Berdasarkan Tujuan ..................................... 31

D. Status Legalitas Mogok Kerja.................................................... 33

E. Perlindungan Hukum Atas Mogok Kerja ............................. 37

F. Mogok Kerja Menurut Internasional Labour Organization ... 39

1. Prinsip Mogok Kerja .......................................................... 39

2. Sasaran Mogok Kerja ....................................................... 40

3. Mogok Kerja Dengan Pengecualian ................................. 43

4. Kerancuan Pelaksanaan Mogok Kerja .............................. 43

G. Langkah-Langkah Mencegah Terjadinya Mogok Kerja ..... 45

1. Pertemuan Pagi Hari (Morning Gathering) ....................... 45

2. Pertemuan Antara Manajemen Dengan Pekerja (Management-Employee Forum) .......................................... 46

3. Kunjungan Keluarga Ke Lokasi Kerja
(Family Gathering) .......................................................... 47

4. Sarana Olah Raga dan Organisasi Kerohanian .............. 48

5. Kegiatan Halal Bi Halal ...................................................... 48

6. Apresiasi Atas Pengabdian dan Prestasi Pekerja .......... 49

BAB III PEMUTUSAN HUBUNGAN KERJA DAN ASPEK

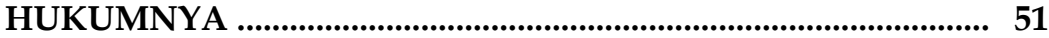

A. Pengertian Pemutusan Hubungan Kerja (PHK) .................. 51

B. Jenis-Jenis Pemutusan Hubungan Kerja (PHK) .................. 54

1. PHK Demi Hukum ......................................................... 54

2. PHK Oleh Pekerja ......................................................... 55

3. PHK Oleh Pengusaha ........................................................ 56 
4. PHK Putusan Pengadilan.

C. Perlindungan Hukum Atas Pemutusan Hubungan Kerja (PHK)

1. Pengertian Perlindungan Hukum.

2. Bentuk Perlindungan Hukum Pemutusan Hubungan Kerja

3. Upaya Hukum Atas Pemutusan Hubungan Kerja ........ 69

D. Pengertian Perselisihan Hubungan Industrial (PHI) .......... 70

E. Jenis-Jenis Perselisihan Hubungan Industrial (PHI) ........... 72

1. Perselisihan Hak .............................................................. 73

2. Perselisihan Kepentingan ............................................... 73

3. Perselisihan Pemutusan Hubungan Kerja (PHK) .......... 74

4. Perselisihan Antara Serikat Pekerja Dalam Satu Perusahaan

F. Penyelesaian Perselisihan Pemutusan Hubungan Kerja (PHK)

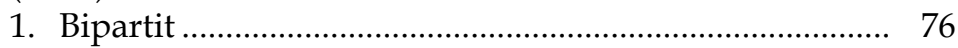

2. Mediasi Hubungan Industrial ...................................... 77

3. Konsiliasi Hubungan Industrial ..................................... 79

4. Arbitrase Hubungan Industrial ................................... 80

5. Pengadilan Hubungan Industrial (PHI) dan Upaya Hukum Kasasi Mahkamah Agung (MA)

BAB IV KAJIAN YURIDIS PUTUSAN MA TENTANG MOGOK
KERJA YANG MENGAKIBATKAN PHK.................................. 83

A. Kronologis Kasus .............................................................. 83

B. Permohonan Perkara Dalam Upaya Hukum Kasasi .......... 87

C. Pertimbangan Hukum Mahkamah Agung ……………..... 92

D. Putusan Hukum Mahkamah Agung................................... 94

E. Kajian Yuridis Putusan Mahkamah Mahkamah Agung Nomor 13 K/Pdt.Sus- PHI/ 2015 tentang Mogok Kerja Yang Mengakibatkan Pemutusan Hubungan Kerja (PHK) 94

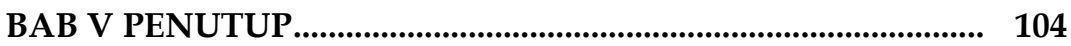

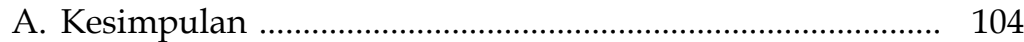

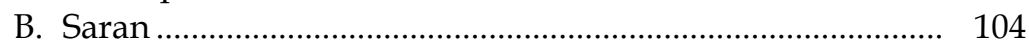

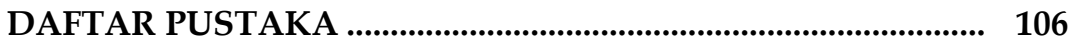

Tentang Penulis............................................................................... 111 


\section{HUKUM KETENAGAKERJAAN:}

ANALISIS PUTUSAN MA TENTANG MOGOK KERJA YANG MENGAKIBATKAN PHK 


\section{BAB I \\ PERSOALAN HUKUM DAN TENAGA KERJA}

Hukum adalah faktor penting dalam permasalahan tenaga kerja. Hal ini karena hukum memberikan kepastian keadilan bagi tenaga kerja. Ketidakpastian hukum bisa menimbulkan berbagai masalah. Pada bagian ini akan diulas bagaimana permasalahan ketenagakerjaan yang terkait dengan hukum. Selain itu, berbagai teori tentang hukum dan keadilan juga akan dijabarkan sebagai landasan analisis selanjutnya pada buku ini.

\section{A. Hukum Ketenagakerjaan dan Permasalahannya}

Dalam sejarah hukum ketenagakerjaan selalu diawali dengan suatu masa yang amat sulit sekali yaitu dimana berbagai perjuangan kelas pekerja dilakukan untuk meraih hak-hak industrial mereka. Dimulai pada awal perkembangan revolusi industri pada abad ke - 19 memberikan dampak terhadap ekonomi dan politik, khususnya di kawasan negara Eropa dan Amerika. Berbagai persoalan ketenagakerjaan seperti pengetatan disiplin, pengintensifan jam kerja, minimnya upah, dan buruknya kondisi kerja selalu melahirkan perlawanan dari kalangan pekerja untuk menuntut perlakuan yang lebih adil dari para pemilik modal.

Lapangan Haymarket, di Chicago, Amerika Serikat menjadi saksi atas kemuakan kelas pekerja atas dominasi kelas borjuis yang telah mencapai puncaknya. Aksi mogok kerja yang dilakukan oleh kurang lebih 400.000 (empat ratus ribu) pekerja Amerika ini menuntut pengurangan jam kerja dari 20 (dua puluh) jam kerja menjadi 8 (delapan) jam kerja dalam sehari. Kemudian dimana aksi ini ditanggapi oleh aparat dengan menembaki para demonstran yang mengakibatkan ratusan kelas pekerja meninggal dunia dan para 
pemimpinnya dihukum mati. ${ }^{1}$

Perseteruan antara pemilik modal dengan pekerja memang sudah lama terjadi sejak bergulirnya revolusi industri. Kehidupan ekonomi dengan hegemoni kapitalisme finansial beroperasi melalui "dis-solution subject", dimanapekerja / buruh tidak dipandang sebagai subjek produksi yang patut dilindungi melainkan sebagai objek yang bisa dieksploitasi. Menurut Karl Marx (1818-1883) dalam teori nilai kerjanya menyatakan bahwa laba kapitalis didasarkan pada eksploitasi pekerja.

Para kapitalis menjalankan tipuan yang agak sederhana dengan membayar pekerjaannya lebih rendah daripada yang seharusnya mereka terima, karena mereka menerima upah yang lebih rendah daripada yang seharusnya mereka terima, karena mereka menerima upah yang lebih rendah daripada nilai yang benar benar mereka hasilkan dalam satu periode kerja. Nilai surplus yang diperoleh dan diinventarisasikan kembali oleh kapitalis adalah basis bagi seluruh sistem kapitalis. ${ }^{2}$

Teori Marx ini merupakan analisis terhadap kesenjangan dibawah kapitalisme dan bagaimana mengatasinya. Marx mencoba menawarkan teori masyarakat kapitalis yang didasarkan pada suatu pandangan tentang hakikat manusia yang sosial dan produktif, namun kapitalisme merusak segalanya hingga memisahkan individu dengan proses produksi.Marx juga memberi isyarat tentang bahaya kapitalisme, menurutnya bahwa bagi kapitalisme akumulasi capital sama sekali tidak berhubungan dengan subjek produksi termasuk pekerja.

Perkembangan hukum ketenagakerjaan di Indonesia selalu berkaitan dengan politik hukum yang diberlakukan oleh penguasa pada saat itu. Pada saat pemerintahan orde baru

${ }^{1}$ Wikipedia, Hari Buruh dan Peristiwa Haymarket, http://www.wikipedia.org, diakses tanggal 12 Juni 2016.

2 George Ritzer, Teori Sosiologi Dari Teori Sosiologi Klasik Sampai Perkembaangan Mutakhir Teori Sosial Postmodern, (Yogyakarta: Kreasi Wacana,2009), hlm. 23. 
misalnya, segala kegiatan dan peringatan hari buruh tidak diperingati sebagai bentuk representasi peranan buruh dalam masyarakat dan ekonomi tetapi lebih dipandang sebagai gerakan yang berhubungan dengan paham komunis yang dapat membahayakan keamanan negara (subversive)yang sangat ditabukan di Indonesia sejak adanya partai komunis pada tahun 1965.

Kedudukan buruh semakin lemah dengan dalih Hubungan Industrial Pancasila, hak buruh dikebiri dengan hanya dapat mendirikan satu serikat pekerja yaitu Serikat Pekerja Seluruh Indonesia (SPSI), serta apabila ada masalah hubungan industrial majikan dapat dibantu oleh militer (Permenaker No. Per. 342 / Men / 1986). ${ }^{3}$

Memasuki era reformasi dan seiring bergulirnya reformasi di tubuh TNI, membuat posisi TNI dan Polri saat ini tidak boleh berpolitik. Berbeda dengan masa orde baru TNI dibentuk selain menjaga keamanan negara tapi juga memegang kekuasaan mengatur negara untuk mengawasi masyarakat agar tunduk pada rezim Soeharto. Kondisi saat itu juga sudah tidak sejalan lagi dengan amanat Undang - Undang Nomor 34 Tahun 2004 tentang TNI, yang menjelaskan bahwa militer bertugas menghadapi ancaman dari luar. Oleh karena itu keterlibatan militer saat ini dalam menangani keamanan di dalam negeri sifatnya dibatasi, dan apabila ada operasi militer diluar perang maka fungsi tersebut harus ada persetujuan presiden.

Dengan demikian maka saat ini apabila ada militer yang membantu pengusaha dalam hubungan industrial maka tindakan tersebut bertentangan dengan UU TNI itu sendiri. Selain itu, di era reformasi dan demokrasi saat ini dimana kebebasan dan menyatakan pendapat telah dijamin konstitusi maka seharusnya militer tidak ikut campur menangani

${ }^{3}$ Asri Wijayanti,Hukum Ketenagakerjaan Pasca Reformasi, (Jakarta: Sinar Grafika, 2013), hlm. 23. 
hubungan industrial. Pemikiran yang keliru ketika ada yang menafsirkan bahwa pekerja sebagai pihak yang dituding melakukan keresahan, padahal pekerja hanya menuntut hak normatif yang semestinya diterima. Sedangkan pengusaha tidak jarang melakukan pelanggaran hukum ketenagakerjaan.

Posisi pekerjaselalu dituding pembuat keresahan, padahal pekerja hanya menuntut pemenuhanhak normatifnya. Sedangkan pengusaha tidak jarang melanggar hukum ketenagakerjaan. Pemerintah tidak hadir untuk melindungi pekerja dan mandul memberikan sanksi padapengusaha yang melanggar hak-hak pekerja. ${ }^{4}$

Memasuki era reformasi yang semula diharapkan akan membangun kondisi hukum, sosial, politik dan ekonomi yang demokratis namun hingga saat ini manfaatnya belum dapat dirasakan oleh kelas pekerja. Penghalang harapan itu tentu berawal dari kepincangan sistem hukum ketenagakerjaan, adanya hambatan bersifat struktural, kultural, dan substansial dari Undang - undang maupun hambatan finansial yang berimplikasi lemahnya penegakan hukum ketenagakerjaan yang berimbas pada kesalahan menempatkan posisi kelas pekerja. Dengan tekanan pertumbuhan ekonomi yang tinggi membuat pemerintah mengutamakan pengusaha ketimbang pekerja.

Dalam sistem perekonomian yang kapitalistik pengusaha diposisikan sebagaipemacu pertumbuhan ekonomi, karena itu pemerintah lebih banyak memfasilitasi kelompok pengusaha ketimbangkelompok pekerja, akibatnya buruh dibayar sangat murah, bahkan termurah di antara negara - negara di Asia. ${ }^{5}$

\footnotetext{
LBH Jakarta, Militer Tidak Layak Urus Sektor Perburuhan, http:/ / www.bantuan hukum.or.id, diakses tanggal 10 Juni 2014.

5Rachmad Syafa'at, Gerakan Buruh dan Pemenuhan Hak Dasarnya: Strategi Buruh Dalam Melakukan Advokasi, (Malang: In-Trans Publising, 2008), hlm. 93.
} 
Perusahaan sebagai simbol dari sistem ekonomi yang dominan selalu menjadi anti - tesis dalam perlindungan hukum terhadap pekerja. Keduanya saling bertentangan antara das Sollen yaitu keharusan dan das Seinyaitu kenyataan. Kesenjangan ini disebabkan adanya perbedaan pandangan dan prinsip antara kepentingan pekerja dengan kepentingan ekonomi ataupun perusahaan. Sementara hukum menghendaki terpenuhinya hak - hak pekerja secara maksimal, namun disisi lain bagi perusahaan hal tersebut justru dirasakan sebagai suatu rintangan karena akan mengurangi laba atau keuntungan. Oleh karena itu fungsi intervensi pemerintah dalam masalah ketenagakerjaan bukan hanya sebagai instrument nilai yang otonom dan independen namun juga harus tampil dalam bagian dari upaya merekayasa sosial (law is a tool of social engineering).

Tidak dapat dipungkiri, terjadi dua pandangan yang berbeda antara pengusaha dan pihak pekerja. Satu sisi pekerja ingin mendapatkan pekerjaan yang ringan dengan pendapatan yang banyak, namun disisi lain pengusaha ingin memberikan upah yang sedikit dan berharap produktifitas yang tinggi dan memperoleh keuntungan yang sebesar - besarnya. ${ }^{6}$

Kontradiksi kepentingan berbeda antara pekerjadengan pengusaha secara ekonomi sosial menimbulkan hubungan subordinatif yang terbingkai dalam hubungan kerja sehingga menimbulkan posisi tidak semitrikal antara keduanya. Dalam konteks inilah kemudian hukum dijadikan sarana untuk memberikan konsekwensi hubungan kerja antara hak dan kewajiban yang harus dijaga dan dilindungi.

Adanya peraturan Undang - Undang ditujukan untuk pengendalian. Baik pemberi kerjamaupun yang diberikan pekerjaan, masing - masing harus

${ }^{6}$ Soedarjadi, Hukum Ketenagakerjaan Indonesia, (Yogyakarta: Pustaka Yustisia, 2008), hlm. 2. 
terkendaliatau harus menundukan diripada segala ketentuan dan peraturan yang berlaku, harus bertanggungjawab dalam melaksanakan kegiatan masing- masing sesuai dengan tugas dan wewenangnya, sehingga keserasian dan keselarasanakan selaluterwujud. ${ }^{7}$

Hubungan kerja merupakan hubungan antara pekerja dan pengusaha yang terjadi karena adanya suatu perjanjian kerja. Menurut Zainal Asyhadie bahwa yang dimaksud dengan hubungan kerja adalah :

Hubungan antara dua pihak yaitu pengusaha dengan pekerja / buruh, dengan suatu perjanjian kerja dimana pihak kesatu (pekerja / buruh) mengikatkan dirinya pada pihak lain (pengusaha) untuk bekerja dengan mendapat upah, dan pengusaha menyatakan kesanggupannya untuk mempekerjakan pekerja / buruhdengan membayar upah. ${ }^{8}$

Dalam Pasal 1 Angka 15 Undang - undang Nomor 13 Tahun 2003 Tentang Ketenagakerjaan bahwa Hubungan Kerja adalah hubungan antara pengusaha dengan pekerja berdasarkan perjanjian kerja yang mempunyai unsur pekerjaan, upah dan perintah. Jadi hubungan kerja itu adalah sesuatu yang abstrak sedangkan perjanjian kerja adalah sesuatu yang konkret.

Perjanjian kerja mempunyai manfaat yang besar bagi para pihak yang mengadakan perjanjian tersebut. Hal ini hendaknya harus disadari karena dengan perjanjian kerja yang dibuat dan ditaati secara baik akan dapat menciptakan suatu ketenangan kerja, jaminan kepastian hak dan kewajiban baik bagi pihak buruh maupun majikan. Akibat lebih jauh nanti produktivitas akan

${ }^{7}$ G. Kartasapoetra, Hukum Perburuhan di Indonesia Berdasarkan Pancasila,(Jakarta: Sinar Grafindo,1998), hlm. 13.

8 Zaeni Asyhadie, Hukum Kerja Hukum Ketenagakerjaan Bidang Hubungan Kerja, (Jakarta: RajaGrafindo Persada,2012), hlm. 50. 
semakin meningkat, sehingga pengusaha akan dapat mengembangkan perusahaannya. Lebih luas lagi dapat membuka lapangan kerja baru yang akhirnya akan mengurangi jumlah pengangguran di Indonesia. ${ }^{9}$

Secara umum pengertian perjanjian kerjadapat dilihat dalam pasal 1 Angka 14 Undang-Undang Nomor 13 Tahun 2003 bahwa perjanjian kerja adalah perjanjian antara pekerja / buruh dengan pengusaha atau pemberi kerja yang memuat syarat - syarat kerja, hak, dan kewajiban pihak. Meskipun suatu perjanjian kerjatelah mengikat para pihak, namun dalam pelaksanaannya sering berjalan tidak seperti apa yang diharapkan sehingga menimbulkan perselisihan faham mengenai hubungan kerja tersebut yangpada akhirnya terjadilah Pemutusan Hubungan Kerja (PHK).

Masih banyak kasus - kasus Pemutusan Hubungan Kerja (PHK) yang disebabkan adanya tuntutan dari pihak buruh / pekerja untuk memperjuangkan hak - hak normatifnya berbuntut pada Pemutusan Hubungan Kerja (PHK). Karena itu kondisi yang terjadisaat inimasih banyak diantara buruh/pekerja yang tidak berani menuntuthak - haknyameskipun belum sesuaidengan aturan yang ada, karenaalasan klasik takut di-PHK. ${ }^{10}$

Proses dalam pembentukan perjanjian kerja merupakan proses yang sangat sensitif dalam menciptakan terjadinya hubungan kerja. Di satu sisi pengusaha merasa telah memberikan kebijakan yang menurut pertimbangan sudah baik dan berharap diterima oleh pekerja, namun disisi lain pekerja mempunyai pertimbangan dan pandangan yang berbeda. Dengan demikian kebijakan yang diberikan menjadi tidak sama dan masing - masing pihak bahkan menunjukan sikap - sikap tidak puas.

9 Zainal Asikin, et.al, Dasar-Dasar Hukum Perburuhan, (Jakarta: RajaGrafindo Persada,2008), hlm. 66.

${ }^{10}$ Lalu Husni, Pengantar Hukum Ketenagakerjaan Indonesia, (Jakarta: RajaGrafindo Persada,2012), hlm. 5. 
Dalam pembentukan suatu Perjanjian Kerja Bersama (PKB) antara pengusaha dan pekerja apabila belum tercapainya suatu kesepakatan, maka kedua pihak agar dapat menahan diri dan tidak mengambil tindakannya sendiri - sendiri. Termasuk tindakan yang dapat merugikan salah satu pihak seperti melakukan tindakan mogok kerja atau melakukan tindakan balasan dengan melakukan Pemutusan Hubungan Kerja (PHK). Agar penyelesaian perselisihan kerja dapat diambil secara bijaksana dan menguntung kedua belah pihak (win - win solution).

Dalam konteks yang amat paradok perlu dilakukan kajian mendasar dalam tataran implementasi hak - hak dasar buruh kemudian dikritisi bahkan dicarikan solusinya. Bukankah kapitalisme finansial, neoliberalisasi, globalisasi ekonomi dan pasar bebas di satu sisi akan berhadap - hadapan secara diametral dengan prinsip - prinsip hak asasi manusiadi sisi lain. ${ }^{11}$

Pada hakikatnya mogok kerja adalah hak dasar bagi pekerja selama dilakukan secara sah, tertib dan damai sebagai akibat gagalnya perundingan, seperti yang tertuang dalam Pasal 137 Undang - Undang Nomor 13 Tahun 2003 Tentang Ketenagakerjaan. Oleh karena mogok kerja adalah merupakan hak dasar, maka sudah tentu adanya ketentuan yang harus dipenuhi sebelum maupun saat melakukan mogok kerja tersebut. Dalam Pasal 3 Keputusan Menteri Tenaga Kerja dan Transmigrasi Republik Indonesia Nomor KEP - 232 / MEN / 2003 tentang Akibat Hukum MogokKerja yang Tidak Sah menyebutkan bahwa mogok kerja tidak sah apabila dilakukan :

1. Bukan akibat gagalnya perundingan;

2. Tanpa pemberitahuan kepada pengusaha dan instansi yang bertanggung jawab di bidang ketenagakerjaan ;

3. Pemberitahuan kurang dari 7 hari sebelum pelaksanaan mogok kerja ;

${ }^{11}$ Rachmad Syafa'at, Op. Cit, hlm. 3. 
4. Isi pemberitahuan tidak sesuai dengan ketentuan Pasal 140 ayat (2) huruf a, b, c, dan d Undang-Undang Nomor 13 Tahun 2003.

Dalam Pasal 140 Ayat (2) Undang - Undang Nomor 13 Tahun 2003 Tentang Ketenagakerjaan mengatur mengenai pemberitahuan mogok kerja yang sekurang - kurangnya memuat:

1. Waktu (hari, tanggal, dan jam) dimulai dan diakhiri mogok kerja ;

2. Tempat mogok kerja ;

3. Alasan dan sebab - sebab mengapa harus melakukan mogok kerja;

4. Tanda tangan ketua dan sekretaris dan / atau masing masing ketua dan sekretaris serikat pekerja sebagai penanggung jawab mogok kerja.

Berdasarkan ketentuan diatas, maka sah atau tidaknya suatu mogok kerja sangat berkaitan dengan kelangsungan hubungan kerja. Mogok kerja yang dilakukan tidak sah dapat mengakibatkan pekerjadikualifikasikan sebagai mangkir. Pekerja yang mangkir tidak berhak atas upah dan pekerja yang dianggap mangkir tidak memenuhi panggilan dari pengusaha maka dianggap mengundurkan diri.Kasus mogok kerja yang berakhir Pemutusan Hubungan Kerja memang sering kali terjadi, mogok kerja yang melibatkan banyak pekerja serta berlangsung lama menyebabkan perusahaan banyak menanggung kerugian. Oleh karena Pemutusan Hubungan Kerja menjadi salah satu solusi yang diambil oleh pengusaha dalam menghadapi potensi kerugian dari mogok kerja tersebut.

Kasus mogok kerja yang berakhir Pemutusan Hubungan Kerja di PT. Sinar Antjol yang pernah penulis angkat melalui karya tulisan ilmiah berupa skripsi yang akan penulis lanjutkan dalam karya tulisan ilmiah berupa tesis, selalu menarik untuk dikaji dari perspektif hukum ketenagakerjaan. Segala persoalan yang terungkap dipermukaan memang terlihat sederhana, padahal akar masalahnya cukup rumit dan disebabkan oleh banyak faktor. "Peristiwa perburuhan yang sering terjadi 
merupakan fenomena gunung es, yaitu persoalan pekerja yang terlihat hanya permukaannya saja namun faktanya akar masalahnya cukup banyak dan sangat rumit" ${ }^{12}$ Mogok kerja tersebutmelibatkan banyak pekerja dan berlangsung dalam waktu yang relatif lama hingga upaya kasasi ke Mahkamah Agung.

Setelah terjadinya mogok kerja akibat perundingan Perjanjian Kerja Bersama (PKB) dan setelah melalui perundingan bipartit dan mediasi maka PT. Sinar Antjol mengajukan gugatan ke Pengadilan Hubungan Industrial. Dimana PT. Sinar Antjol meminta kepada majelis hakim untuk menyatakan bahwa mogok kerja tidak sah sehingga Pemutusan Hubungan Kerja yang dilakukannya adalah sah menurut hukum. Namun gugatan tersebut ditolak oleh hakim pemeriksa perkara dan memerintahkan kepada penggugat untuk mempekerjakan kembali para tergugat sesuai dengan jabatan dan tempat kerja semula.Dengan keputusan tersebut PT. Sinar Antjolmengajukan kasasi ke Mahkamah Agung. Dan berdasarkan Putusan Mahkamah Agung Nomor 13 K/Pdt.SusPHI/2015 kasasi tersebut dikabulkan sekaligus membatalkan putusan Pengadilan Hubungan Industrial dan juga Pemutusan Hubungan Kerja yang dilakukan PT. Sinar Antjol adalah sah.

Apabila kita perhatikan dari dua keputusan pengadilan diatas kedua - duanya tidaklah menguntungkan pihak pekerja. Perlindungan hukum yang diberikan kepada pekerja seolah tidak tampak dalam keputusan Pengadilan Hubungan Industrial. Meskipun Pengadilan Hubungan Industrial (PHI) telah memerintahkan pada penggugat untuk mempekerjakan kembali para pekerja sesuai dengan jabatan dan tempat kerja semula. Namun dapatkah putusan tersebut dapat dilakukan eksekusi apabila pengusaha tidak dengan sukarela melaksanakan amar putusan tersebut. Kondisi ini menjadi sangat riskan jika Pemutusan Hubungan Kerja dilakukan sewenang - wenang oleh pengusaha. Kemudian Putusan Mahkamah Agung yang berbanding terbalik dengan putusan

${ }^{12}$ Ibid, hlm. 11. 
sebelumnya yang mengabulkan Pemutusan Hubungan Kerja yang dilakukan adalah sah, maka ini adalah jelas merugikan pekerja.

Dalam proses penegakan hukum ketenagakerjaan adalahmerupakan suatu proses rangkaian dalam mewujudkan konsep - konsep yang abstrak menjadi kenyataan. Oleh karena itu apabila hendak menegakkan hukum, maka hukum harus dipandang sebagai kesatuan sistem untuk menghindari kepincangan dalam sistem hukum itu sendiri. Maka Lawrence M. Friedman mengatakan bahwa hukum merupakan gabungan antara komponen substansi (legal substantion), struktur (legal structure), budaya (legal culture) dalam menguji sebuah efektifitas hukum.

Friedman menggambarkan tiga unsur sistem hukum adalah dengan mengibaratkan struktur hukum seperti mesin, substansi adalah apa yang dihasilkan atau atau yang dikerjakan oleh mesin, dan kultur atau budaya hukum adalah apa saja atau siapa saja yang memutuskan untuk menghidupkan atau mematikan mesin itu serta memutuskan bagaimana mesin itu digunakan. Satu komponen pendukung tidak berfungsi niscaya sistem mengalami disfunction(pincang). Yang dimaksud dengan sistem hukum menurut Friedman adalah aturan, norma, dan prilaku nyata manusia yang berada dalam sistem itu. ${ }^{13}$

Seperti yang telah diuraikan diatas bahwa kepincangan penegakan hukum ketenagakerjaan memang bermula dari tidak berfungsinya sistem hukum ketenagakerjaan yang sangat mendasar baik yang bersifat struktural, kultural, dan substansi perundang - undangan atau kebijakan, maupun yang sangat fundamental seperti hambatan finansial yang dapat berimplikasi pada lemahnya penegakan hukum

${ }^{13}$ H.A.S Natabaya, Sistem Peraturan Perundang-undangan Indonesia, (Jakarta: Konstitusi Press dan Tatanusa, 2008), hlm. 23. 
ketenagakerjaan yang juga berimplikasi pada kompleksitas masalah ketenagakerjaan yang kerap kali terjadi antara pekerja dan pengusaha. Oleh karena itu menjaga keseimbangan dan proporsionalitas dalam hubungan kerja menjadi syarat utama, baik pekerja dan pengusaha harus menjadi partner yang akan selalu dapat saling membantu agar dapat mensukseskan tujuan masing - masing.

\section{B. Fokus Masalah dan Tujuan Kajian}

Berdasarkan uraian latar belakang masalah diatas, maka dapat dibuat identifikasi masalah sebagai berikut: 1) Dalam putusan Mahkamah Agung Nomor 13 K/Pdt.Sus- PHI/2015 bahwa mogok kerja dapat mengakibatkan Pemutusan Hubungan Kerja (PHK). 2) Mogok kerja dapat mengakibatkan Pemutusan Hubungan Kerja (PHK) menurut Undang-Undang No. 13 Tahun 2003 tentang Ketenagakerjaan.

Berdasarkan pokok permasalahan diatas, maka kajian ini bertujuan untuk mengetahuibentuk putusan Mahkamah Agung Nomor 13 K/Pdt.Sus- PHI/2015 tentang mogok kerja yang mengakibatkan Pemutusan Hubungan Kerja (PHK). Selain itu, kajian dalam buku ini juga akan mengungkap bentuk mogok kerja yang mengakibatkan Pemutusan Hubungan Kerja (PHK) ditinjau dari Undang - Undang Nomor 13 Tahun 2003 tentang Ketenagakerjaan.

Adapun manfaat dari kajian di buku ini adalah manfaat secara praktis dan manfaat secara teoritis. Manfaat secara praktis yaitu untuk menambah pengetahuan masyarakat khususnya para pekerjatentangPutusan MahkamahAgung Nomor 13 K / Pdt. Sus- PHI/2015 tentang mogok kerja yang dapat mengakibatkanPemutusan Hubungan Kerja (PHK) ditinjau dari Undang - UndangNomor 13 Tahun 2003 tentang Ketenagakerjaan. Selain itu, kajian ini juga bermanfaat untukmenambah pengetahuan Mahasiswa/idi berbagai Universitas mengenaiPutusan MahkamahAgung Nomor $13 \mathrm{~K} /$ Pdt. Sus PHI/2015 tentang mogok kerja yang dapat mengakibatkanPemutusan Hubungan Kerja (PHK) ditinjau dari 
Undang-UndangNomor $13 \quad$ Tahun 2003 tentang Ketenagakerjaan.

Dalam segi teoritis, kajian ini akan bermanfaaat untuk memberikankonstribusi khasanah kepustakaan yaitu dengan menambah koleksi bacaanmengenaiPutusan MahkamahAgung Nomor 13 K / Pdt. Sus- PHI / 2015 tentang mogok kerja yang mengakibatkanPemutusan Hubungan Kerja (PHK) ditinjau dari Undang - UndangNomor 13 Tahun 2003 tentang Ketenagakerjaan.

\section{Teori Hukum dan Keadilan}

Kerangka teori yang digunakan penulis sebagai ujung tombak dalam analisis kajian ini, terdiri atas Grand Theory (Teori Dasar), Middle Theory (Teori Menengah), dan Applied Theory (Teori Terapan).Teori dasar yang digunakan adalah teori dari Hugo Krabble.Teori menengah yang digunakan adalah teori dari John Rawls. Sedangkan teori terapan

\section{Teori Kedaulatan Hukum Hugo Krabble}

Dalam kajian buku iniGrand Theory yang penulis gunakan adalah teori kedaulatan hukum menurut Hugo Krabbe. Menurut Hugo Krabbe, teori kedaulatan hukum (Rechts Souvereiniteit Theory) adalah "aldus moet ook van recht de heerscappij gezocht worden in de reactie van het rechtsgevoel, en ligt dus het gezag niet buiten maar in den mens". ${ }^{14}$ Pendapat Krabbe tersebut telah menjelaskan, demikian halnya dengan kekuasaan hukum yang harus kami cari dalam reaksi perasaan hukum dimana kekuasaan hukum tidak terletak di luar manusia tetapi di dalam manusia. Dengan demikian hukum itu berdaulat diatas segalanya bahkan termasuk negara. Menurut Hugo Krabbe, negara yang baik itu negara yang berdaulat dalam hukum ataupun negara hukum (rechtstaat)yaitu dimana setiap tindakan negara harus bisa dipertanggungjawabkan dihadapan hukum. Kedaulatan hukum bersumber kesadaran masyarakat yang mempunyai

${ }^{14}$ L. J. Van Apeldorn, Pengantar Ilmu Hukum, (Jakarta: Pradnya Paramita, 2004), hlm. 168 
rasa untuk membuat hukum yang baik. Dengan rasa kesadaran akan hukum maka manusia mengeluarkan perasaan ataupun kesadaran hingga mampu mengeluarkan suatu reaksi untuk menetapkan reaksi yang baik, adil, dan sebagainya.

Kebebasan berkontrak dalam melakukan suatu perjanjian adalah merupakan bentuk dari adanya kedaulatan hukum yang dimiliki setiap individu dalam melakukan perbuatan hukum. Dimana individu menurut kepentingan secara otonom berhak dapat melakukan perjanjian dengan individu ataupun kelompok masyarakat. Kekuatan mengikat perjanjian tersebut setara dengan hukum yang dibuat oleh negara antara legislatif dan pemerintah, dan siapa yang mengingkarinya maka dapat dituntut pertanggungjawabannya di hadapan hukum.

Dalam Teori Pacta Sunt Servanda, suatu kontrak yang mengikat para pihak mengikatnya sama dengan kekuatan undang - undang yang dibuat oleh parlemen (bersama dengan pemerintah) tetapi pacta sunt servandaberlaku hanya sebagai sebuah teori dasar (grand theory) artinya ketika diwujudkan dalam praktik maka diperlukan berbagai penafsiran dan penyesuaian. ${ }^{15}$

Dalam Teori Pacta Sunt Servandayang diajarkan Hugo Grotius bersifat universal yaitu dimana wadah dari mengikatnya sebuah kontrak tidak lain adalah dari hukum alam itu sendiri.Menurut Mariam Darus Badrulzaman bahwa "keterikatan para pihak pada suatu perjanjian tidak semata terbatas pada apa yang diperjanjikan tetapi juga terhadap unsur lain sepanjang dikehendaki kebiasaan dan kepatutan secara moral". ${ }^{16}$ Sejak zaman Yunani dimana Plato dan Aristoteles hingga Romawi telah disadarkan

15 Munir Fuady, Teori - Teori Besar (Grand Theory) Dalam Hukum, (Jakarta: Kencana,2013), hlm. 226.

16 Mariam Darus Badrulzaman, Kompilasi Hukum Perikatan, (Bandung: Citra Adytia Bakti,2001), hlm. 88. 
bahwa kepatutan (equity) sangat diperlukan untuk menjaga pelaksanaan undang - undang karena kepatutan (equity) terletak diluar hukum yang tentu menuntut keadilan dalam situasi tertentu.

Menurut Teori Kepatutan Hukum (Equity Of Law Theory) G.W Paton, menegaskan "kepatutan (equity) dalam pelaksanaannya tidaklah berlawanan dengan hukum, tetapi pengaruhnya semakin kuat ketika dalam penyelesaian suatu sengketa yaitu dimana ketika aspek hukum tidak mengaturnya". ${ }^{17}$ Karena itu dalam sistem Civil Lawasas itikad baik, kepatutan (equity) atau kepantasan akan membantu dalam suatu perumusan penyalahgunaan hak, dimana yang semula hanya dibatasi pada pelanggaran undang - undang (hukum) namun kemudian pada perkembangannya didasarkan kepada nilai - nilai kepatutan (equity).Pertimbangan pada nilai kepatutan (equity) inilah yang diharapkan akan mengarahkan hakim kepada putusan yang seadil - adilnya berdasarkan kepatutan (et aequo et bono).

Equity atau kepatutan tidak bermaksud untuk mengubah atau mengurangi keadilan hukum, melainkan sebatas memberikan koreksi dan atau melengkapi dalam keadaan individu tertentu serta kondisi kasus tertentu. Dengan demikian "summa iustitia summa iniuria" tidak akan terjadi, karena nilai keadilan dalam hubungan antara individu dikembalikan pada proporsi yang sewajarnya. ${ }^{18}$

Pada awalnya, perkembangan suatu perbuatan melawan hukum (Onrechtmatige Daad), pada Pasal 1365 KUHPerdata diinterpretasikan secara sempit yaitu hanya sebatas perbuatan melanggar undang undang. Interpretasi

${ }^{17}$ Agus Yudha Hernoko, Hukum Perjanjian (Asas Proporsionalitas Dalam Kontrak Bisnis), (Jakarta: Kencana, 2013), hlm. 66.

${ }^{18} \mathrm{Ibid}, \mathrm{hlm} .67$. 
ini terkesan sangat formalisticlegalistic, yaitu dimana yang dimaksud perbutan melawan hukum hanya sebatas yang diatur dalam undang - undang saja sedang diluar pengaturan undang - undang meski merugikan orang lain bukanlah merupakan perbuatan melawan hukum. Interpretasi sempit inilah justru mengakibatkan terusiknya rasa keadilan hukum di masyarakat. Akhirnya Hoge Raad melakukan terobosan baru dengan melakukan interpretasi terhadap Pasal 1365 KUHPerdata.

PutusanHooge Raad31 Januari 1919 dalam kasus Lindenbaum dan Cohen yang memutuskan yang dimaksud dengan perbuatan melawan hukum adalah berbuat atau juga tidak berbuat yang dapat melanggar hak orang lain, bertentangan dengan kewajiban hukum pelaku, bertentangan dengan kesusilaan, bertentangan dengan kecermatan yang patut (equity) harus diperhatikan dalam lalu lintas masyarakat terhadap diri dan barang orang lain. ${ }^{19}$

PutusanHooge Raad 31 Januari 1919 pada perkara Lindenbaum dan Cohen, merupakan tonggak penting dalam perluasan arti perbuatan melawan hukum (Onrechtmatige Daad). Dalam perkara ini melibatkan dua kantor percetakan yang saling bersaing, satu milik Lindenbaum dan satu milik Cohen. Pada suatu hari, pegawai yang bekerja pada kantor Lindenbaum dibujuk oleh Cohen supaya memberitahukan nama - nama pelanggannya berikut penawaran yang diberikan pada mereka. Dengan data - data tersebut Cohen bisa memanfaatkannyauntuk membuat suatu penawaran terbaru yang membuat orang memilih kantor percetakannya daripada kantor Lindenbaum.

Untung perbuatan Cohen dengan cepat diketahui Lindenbaum. Akibatnya, Lindenbaum langsung mengajukan gugatan terhadap Cohen di pengadilan

${ }^{19} \mathrm{Ibid}, \mathrm{hlm} .72$. 
Amsterdam. Kemudian juga selain mengajukan gugatan perbuatan melawan hukum terhadap Cohen, Lindenbaum juga meminta ganti rugi atas perbuatan Cohen tersebut. Pada tingkat pertama Cohen kalah, tetapi tingkat banding justru Lindenbaum yang kalah. Di tingkat banding dikatakan bahwa tindakan Cohen tidak dianggap sebagai suatu perbuatan melawan hukum karena tidak dapat ditunjukkan suatu pasal dari undang-undang yang dilanggar Cohen.Akhirnya melalui putusan Hoge Raadtanggal 31 Januari 1919, Lindenbaum dinyatakan sebagai pemenang. Hoge Raadmenyatakan bahwa, pengertian dalam perbuatan melawan hukum pasal 1401 BW (KUHperdata Belanda) termasuk pula suatu perbuatan yang dapat melanggar hak orang lain dan bertentangan dengan kewajiban hukum pelaku, bertentangan dengan kesusilaan, serta bertentangan dengan kepatutan (equity).

KUHPerdata memang tidaklah mendefinisikan dan merumuskan perbuatan melawan hukum. Rumusan tersebut diserahkan pada doktrin dan yurisprudensi. Pasal 1365 KUHPerdata hanyalah mengatur, barang siapa melakukan perbuatan melawan hukum yang dapat menyebabkan kerugian bagi orang lain maka kewajibannya mengganti kerugian yang ditimbulkannya. Belanda telah memasukkan peristiwaHoge Raad 31 Januari 1919 tersebut menjadi salah satu Pasal padaBurgelijk Wetboek. Interpretasi teleologis - ekstensif Pasal 1365 pada dasarnya merupakan penerapan prinsip teori kepatutan (equity)yang pada akhirnya mampu memberi keadilan dan kepastian hukum sebagaimana yang diharapkan dalam lalu lintas hidup di masyarakat.

\section{Teori Keadilan John Rawls}

Dalam penulisan buku iniMiddle Theory yang penulis gunakan adalah teori keadilan hukum menurut John Rawls. Menurut John Rawls, bahwa teorikeadilan (Justice as fairness) yang memadai harus dibentuk dengan pendekatan kontrak, 
dimana asas keadilan yang dipilih harus benar - benar merupakan hasil kesepakatan bersama semua person yang bebas, rasional dan sederajat. Dengan demikian teori keadilan itu akan mampu menjamin pelaksanaan hak dan juga kewajiban secara adil bagi semua orang, oleh karenanya setiap teori keadilan hukum yang tidak berbasis kontraktual harus dikesampingkan demi kepentingan keadilan itu sendiri. John Rawls menyebutkan "keadilan "justice as affairness"yang ditandai adanya prinsip rasionalitas, kebebasan, dan kesamaan". ${ }^{20}$ Oleh karenanya John Rawls merumuskan dua prinsip keadilan, yaitu :

a. Prinsip I : The greatest equal principle, bahwa setiap orang harus memiliki hak yang sama atas kebebasan dasar yang paling luas, seluas kebebasan yang sama bagi semua orang. Ini merupakan hal yang paling mendasar (hak asasi) yang harus dimiliki semua orang. Dengan kata lain, hanya dengan adanya jaminan kebebasan yang sama kepada semua orang maka keadilan akan terwujud (prinsip kesamaan hak).21

b. PrinsipII : ketidaksamaan dalam sosial dan ekonomiharus diatur sedemikian rupa,sehingga perlu diperhatikan prinsip berikut:

1) The different principle, dan

2) The principle of fair equality of opportunity.

Prinsip ini diharapkan dapat memberikan keuntungan besar kepada orang yang kurang beruntung (prinsip perbedaan objektif). ${ }^{22}$

Dengan penekanan yang kuat pada pentingnya memberi peluang yang sama pada semua pihak, John Rawls berusaha agar keadilan tidak terjebak pada ekstremisme kapitalisme atau sosialisme. Karenanya John Rawls

${ }^{20}$ Andre Ata Ujan, Keadilan dan Demokrasi (Telaah Filsafat Politik John Rawls), (Yogyakarta: Kanisius,1999), hlm. 71.

${ }^{21}$ Agus Yudha Hernoko, Op. Cit, hlm. 56.

${ }^{22}$ Ibid, hlm. 57. 
memberikan pedoman sebagai berikut : ${ }^{23}$

a. Prinsip I, yaitu bahwa The greatest equal principleharus lebih diprioritaskan dari prinsip II apabila keduanya berkonflik.

b. Prinsip II angka 2), yaitu bahwa The principle of fair equality of opportunityharus lebih diprioritaskan daripada angka 1) yaitu The different principle.

Keadilan harus difahami sebagai fairness, artinya bahwa tidak hanya mereka yang memiliki bakat dan kemampuan yang lebih baik saja yang berhak menikmati manfaat sosial yang lebih banyak, tetapi keuntungan tersebut juga harus membuka peluang bagi mereka yang kurang beruntung untuk meningkatkan prospek hidupnya. The different principletidaklah menuntut manfaat yang sama (equal benefit)bagi semua orang, melainkan manfaat yang sifatnya timbal balik (reciprocal benefit), misalnya seorang pekerja yang terampil tentunya akan lebih dihargai dibandingkan dengan pekerja yang tidak terampil.

Dengan demikian keadilan sebagai kesetaraan (fairness) sangat menekankan asas resiprositas tidak hanya sekedar "simply reciprocity"tanpa melihat perbedaan yang objektif diantara tiap anggota mayarakat. Oleh karenanya, agar terjamin suatu aturan main yang objektif maka keadilan yang dapat diterima sebagai fairness adalah pure prosedural justiceartinya keadilan sebagai fairness atau kesetaraan harus berproses sekaligus terefleksi ataupun tercermin melalui prosedur yang adil untuk menjamin hasil yang adil pula.

Filosofi keadilan adalah merupakan makna untuk mencapai asas proporsionalitas. Aristoteles menggambarkan bahwa "justice consists in treating equals equally and unequals unequally, in proportion to their inequality". ${ }^{24}$ Sedangkan Ulpianus meyatakan bahwa keadilan sebagai, "justitia est

${ }^{23} \mathrm{Ibid}, \mathrm{hlm} .58$

${ }^{24} \mathrm{Ibid}, \mathrm{hlm} .84$. 
constans et perpetua voluntas ius suum cuique tribuendi". Aristoteles membatasi keadilan pada prinsip bahwa yang sama dapat di perlakukan secara sama dan yang tidak sama juga dapat diperlakukan tidak sama secara proporsional. Sedang Upianus menggariskan keadilan pada kehendak yang terus menerus dan tetap memberikan pada masing masing yang menjadi haknya. Berdasarkan pengertian tersebut, bahwa keadilan dapat terwujud apabila sesuatu yang diberikan pada seseorang sebanding dengan yang seharusnya dia terima. Dengan demikian pada hakikatnya gagasan itu menjadi titik tolak asas proporsionalitas dalam suatu hubungan kontraktual.

Pada teori etis dan utilitas, teori etis yang dipelopori Aristoteles, bahwa tujuan hukum adalah untuk mewujudkan keadilan (rechts vaardigheid atau justice)baik keadilan distributif atau keadilan komulatif. Teori utilitas yang dipelopori oleh jeremy bentham, menekankan bahwa tujuan hukum ialah untuk mewujudkan apa yang berfaedah ataupun berguna (doelmatig)bagi orang, yakni mewujudkan kebahagiaan sebanyak - banyaknya. ${ }^{25}$

Berdasarkan pengertian keadilan tersebut, bahwa keadilan ialah tuntutan mengenai suatu yang esensial dari setiap individu sebagai hak yang tidak boleh dilanggar atau dihalangi dan dijamin melalui formula hukum yang berisi hak dan kewajiban dalam pergaulan sosial. Keadilan dapat ditransformasikan melalui berbagai kepentingan kehidupan fisik dan lahiriah, ekonomi, sosial, politik, budaya, agama serta spritualitas. Hal tersebut memperlihatkan keberadaan hukum itu merupakan sarana untuk mewujudkan kebahagiaan dan kesejahteraan hidup lahir dan batin dalam kehidupan sesama. Mengayomi manusia itu dengan perlindungan secara masif, dengan mencegah tindakan

${ }^{25}$ Asep Warlan Yusuf, Hukum dan Keadilan, (Jurnal Ilmu Hukum: Universitas Padjajaran, 2015), Vol. 2, hlm. 6. 
sewenang - wenang dan juga secara aktif bisa menciptakan kondisi kemasyarakatan yang manusiawi yang memungkinkan proses kemasyarakatan berlangsung secara wajar sehingga secara adil setiap manusia memperoleh kesempatan yang luas dan sama untuk mengembangkan potensi kemanusiannya.

\section{Teori Hukum Roscoe Pound}

Dalam penulisan buku iniApplied Theory yang penulis gunakan ialah teori perlindungan hukum Roscoe Pound. Menurut Roscoe Pound, pada teori perlindungan hukumnya (Sociological Jurisprudence)bahwa kepentingan manusia terbagi menjadi 3 (tiga) macam kepentingan yaitu, "public interest (kepentingan umum), sosial interest (kepentingan pada masyarakat), dan privat interest (kepentingan individual)" ${ }^{26}$

Kepentingan umum (public interest) yang paling utama "meliputi kepentingan dari suatu negara sebagai badan hukum dalam mempertahankan kepribadian dan substansinya, meliputi kepentingan negara sebagai penjaga kepentingan masyarakat". ${ }^{27}$

Ada enam kepentingan masyarakat (sosial interest) yaitu antara lain kepentingan masyarakat kepentingan keselamatan umum, kepentingan lembaga sosial, kepentingan masyarakat terhadap kerusakan moral, kepentingan masyarakat dalam pemeliharaan sumber sosial, kepentingan masyarakat dalam kemajuan umum dan kepentingan masyarakat dalam kehidupan manusia secara individual. ${ }^{28}$

Ada tiga kepentingan individual (privat interest), yaitu antara lain "kepentingan kepribadian (interests of personality)misal seperti kebebasan mengemukakan

${ }^{26}$ Salim HS dan Erlis Septiana Nurbani, Penerapan Teori Hukum Pada Penelitian Tesis dan Disertasi, (Jakarta: Raja Grafindo Persada,2013), hlm. 266.

${ }^{27} \mathrm{Ibid}, \mathrm{hlm} .267$.

${ }^{28} \mathrm{Ibid}, \mathrm{hlm} .268$. 
pendapat, kepentingan hubungan rumah tangga (interests in domestic) seperti perlindungan perkawinan dan kepentingan substansi (interests of substance) seperti kemerdekaan industri dan kontrak". ${ }^{29}$ Teori perlindungan hukum menjadi penting karena merupakan unsur yang harus ada dalam suatu negara. Dalam setiap pembentukan negara pasti didalamnya ada hukum yang mengatur mengenai warga negaranya. Dalam suatu negara pasti terjadinya suatu hubungan, baik itu antara sesama warga negara maupun antara negara dengan warga negaranya. Hubungan inilah yang menimbulkan hak dan kewajiban, dimana perlindungan hukum menjadi hak warga negara dan memberi perlindungan hukum menjadi kewajiban negara.

Dalam fungsinya sebagai perlindungan kepentingan manusia hukum mempunyai tujuan. Hukum mempunyai sasaran yang hendak dicapai. Tujuan pokok hukum yaitu menciptakan tatanan masyarakat yang tertib, membuat ketertiban dan keseimbangan. Dengan tercapainya ketertiban di dalam masyarakat diharapkan kepentingan manusia akan terlindungi. Dalam mencapai tujuannya itu hukum bertugas membagi hak dan kewajiban antar perorangan di dalam masyarakat, membagi wewenang dan mengatur cara memecahkan masalah hukum serta memelihara kepastian hukum. ${ }^{30}$

Ada 3 (tiga) hal yang dapat dianalisis dari pandangan Sudikno Mertokusumo yaitu fungsi hukum, tujuan hukum, dan tugas hukum. Fungsi hukum adalah melindungi kepentingan manusia, tujuan hukum menciptakan tatanan masyarakat yang tertib, ketertiban masyarakat dan seimbang. Masyarakat yang tertib merupakan masyarakat yang teratur, sopan dan menaati berbagai peraturan perundang - undangan dan peraturan yang hidup dan

29Ibid, hlm. 269.

30 Sudikno Mertokusumo, Mengenal Hukum Suatu Pengantar, (Yogyakarta: Liberty,1999), hlm. 71. 
berkembang dalam masyarakat. Ketertiban merupakan suatu keadaan dimana masyarakatnya hidup serta teratur. Keseimbangan adalah keadaan dimana masyarakat hidup seimbang dan sebanding artinya tidak ada masyarakat yang dibedakan antara satu dengan yang lainnya atau sama rata dan sama rasa. Pemahaman inilah yang kemudian difahami sebagai perlindungan hukum pancasila dimana perlindungan hukum tersebut bersumber dari pancasilasebagai ideologi dan falsafah bangsa yang sekaligus memberikan perlindungan terhadap harkat dan martabat serta pengakuan terhadap hak asasi manusia yang dimiliki subjek hukum dari tindakan kesewenang wenangan.

Menurut teori perlindungan masyarakat lemah (social weakness protection theory)Hugo Sinzheimer, atau dalam bahasa Jerman disebut sebagaiTheorie Schutz der Sozial Schwache.

Selalu ada subordinasi dalam masyarakatyaitu di antara mereka yang memerintahkan(command) dan mereka yang mematuhi(obey). Antara mereka yang membuat peraturan dan keputusan, dengan mereka yang mematuhi aturandankeputusan tersebut. Kekuasaan untuk memerintah ini dalam arti kemampuan untuk memastikan bahwa kebijakan, aturan dan keputusan yang dibuatdipatuhisebagai adanya kekuatan sosial(social power). ${ }^{31}$

Menurut teori ini yang menjadi sasaran adalah masyarakat yang berada dalam posisi tawar yang lemah, baik secara ekonomis maupun lemah dari aspek yuridis.

Dalam konteks hukum perburuhan, Hugo Sinzheimermenaruh perhatian kepada fenomena kekuatan sosial. Relasi kerja sebagai sebuah hubungan kekuasaan dominan dan subordinatif, yang menurut Marxian bahwa

31 Surya Candra, Menemukan Kembali Hukum Perburuhan yang Sejati, http:// www.turc.or.id, diakses 21 november 2016. 
subordinasi terhadap buruh merupakan hasil dari kepemilikan perusahaan sebagai pemilik modalatau alat produksi. Dengan di bawah kapitalisme, kesetaraan kontrak yang diasumsikan antara majikan dan buruh kenyataannya hanya sebuah fiksi atau khayalan yang kemudian dikuatkan oleh dominasi majikan serta subordinasi terhadap buruh. Dan Hugo Sinzheimer ingin mengoreksi mistifikasi atau pengecohan situasi ketergantungan buruh ini.Hugo Sinzheimer menegaskan bahwa dengan secara eksplisit dan tegasdiakuipada peraturan perundang - undangan, maka mistifikasi atau pengecohan hukum dapat dihapuskan. Pada titik ini,hukum perburuhan menjadi 'hukum perburuhan yang berpengaruh' (the law of dependent labour), yang muncul sebagai suatu upaya untuk modernisasi kekuasaan majikanagar memerintah dengan menggunakan kombinasi unsur - unsur dan mekanisme hukum.

Esensi inilah yang kemudian disebut sebagai anthropologiHugo Sinzheimer sebagai "bapak hukum perburuhan", yaitu bahwa keyakinan tujuansesungguhnya dari legislasi peraturan perburuhan adalah untuk meningkatkan kebebasan, harga diri dan juga kepribadian buruh secara individual dankeseluruhan, untuk membantu mewujudkan emansipasi manusia sebagai sesuatu yang berbeda dari yang merupakan khayalan. Dengan demikian maka tujuan praktis dari hukum perburuhan akademis adalah untuk mempromosikan reformasi legislative ke arah itu.

\section{Preposisi}

Berdasarkan teori diatas maka penulis merumuskan suatu preposisi atau jawaban sementara dalam penelitian ini, yaitu sebagai berikut :

1. Bentuk putusan Mahkamah Agung Nomor $13 \mathrm{~K} /$ Pdt. Sus PHI / 2015 tentang mogok kerja yang dapat mengakibatkan Pemutusan Hubungan Kerjaadalah mogok kerja yang dilakukan dengan melanggar ketentuan disiplin kerja. 
Mogok kerja dengan melakukan sweeping kepada pekerja lain, melakukan penutupan pintu gerbang pabrik, dan membawa pekerja dari perusahaan lain untuk ikut aksi mogok kerja dapat membuat mogok kerja menjadi tidak sah atauillegal dan tidak berdasar hukum. Sehingga adanya alasan bagi Mahkamah Agung untuk mengabulkan permohonan Pemutusan Hubungan Kerja.

2. Bentuk mogok kerja yang mengakibatkan Pemutusan Hubungan Kerja (PHK) ditinjau dari Undang - Undang Nomor 13 Tahun 2003 tentang Ketenagakerjaan adalah mogok kerja bukan akibat gagal perundingan. Menurut Pasal 6 Kepmenaker Nomor 232 Tahun 2003 tentang akibat hukum mogok kerja yang tidak sah dikualifikasikan sebagai mangkir. Apabila Pekerja tidak memenuhi panggilan 2 (dua) kali berturut - turut dalam tenggang waktu 7 (tujuh) hari dalam pemanggilan secara patut dan tertulis maka pekerja dianggap mengundurkan diri. Dari ketentuan - tersebut jelas bahwa mogok kerja yang tidak sah dapat mengakibatkan Pemutusan Hubungan Kerja (PHK). 